\title{
Responsiveness of public policy and its impact on education management: An empirical assess- ment from Indonesia
}

\author{
Andriansyah Andriansyah ${ }^{a^{*}}$, Taufiqurokhman Taufiqurokhmana and Ismail Suardi Wekke \\ ${ }^{a}$ Universitas Prof. Dr. Moestopo (Beragama), Indonesia \\ ${ }^{b}$ Sekolah Tinggi Agama Islam Negeri (STAIN) Sorong, Indonesia

CH R O I CLE A B T T A C T \\ Article history: \\ Received: October 7, 2018 \\ This paper examines the relationship between public policy and education management in Indo- \\ Received in revised format: No- \\ nesia by looking at various indicators influencing the public policy and the education management. \\ vember 29, 2018 \\ Accepted: December 16, 2018 \\ For education management, factors like education achievement at elementary \& higher school, \\ college enrolment, job market in both local and international levels and social development are \\ observed. Public policy is studied through work force development, higher education, brain drain, \\ public safety, constitutional convention, job approval, legislature and operation policies. To exam- \\ ine this association, a survey questionnaire is developed and presented on various respondents \\ regarding public policy and education management. A sample of 327 respondents is empirically \\ examined and it is observed that the effect of work force development on elementary school \\ achievement was significant while the effect of brain drains, job approval and legislature were \\ crucial for the presented indicators of education management. Further studies can be conducted \\ while considering other aspects of both public policy and education. \\ December 18, 2018 \\ Keywords: \\ Public Policy \\ Education Management \\ Social development \\ Indonesia
}

\section{Introduction}

For the development of public policies, every year Indonesian government spends significant amount of money on laws, regulations and their local implications. However, various policies are revoked by the National Government because they are not symmetrical with the higher level of regulations and serious criticism has been faced from the public. In recent years, government of Indonesia has decided to focus on various locations which are not under regulations and decided to reconsider some other sites for the implementation of new laws and procedures. For the development processes in public policy and its improvement, it is necessary to promote policy implication and spend significant budget. Thus, a new institution under the title of Policy Analysts Functional Position (JFAK) was recently formed, dealing with the local and national government. The strategic role for JFAK is to work for the significant growth and implementation of various types of public policies in Indonesia while solving the issues of individuals through policy making mechanism. The supervision of JFAK is the core obligation of State Administrative Institutions (SAI), working through policy analyst association (PAA). It 
is observed that working with both national and sub national level, JFAK is dealing with the policy analysts and contributing towards the strategic development of polices in Indonesia. The members working in the organization are highly trained with significant capacity to provide high quality policy related recommendations. For the sustainable growth in the country, it is observed that quality policy making, and governance mechanism provides higher living standards for the local community. Consideration of various stakeholders from local regions provides a way for the wide spectrum regarding social, moral, religious, economic, and political variables for policy making and its future implications.

As per the significance of policy reforms, from the context of education, various strategic plans have been implemented during the last two decades. The upgraded development for the spending of public budget of 20 percent on education has witnessed significant involvement. Meanwhile, some educational institutions have been decentralized from various cities and local locations for their proper and smooth functioning in the country. To boost the operational activities in the schools, government has increased the resources through School Operational Assistance Grant Program (OAGP) and insisting the parents for the enrollment of their children. Fig. 1 demonstrates the percentage of GDP spending on education for the period 2000-2016.

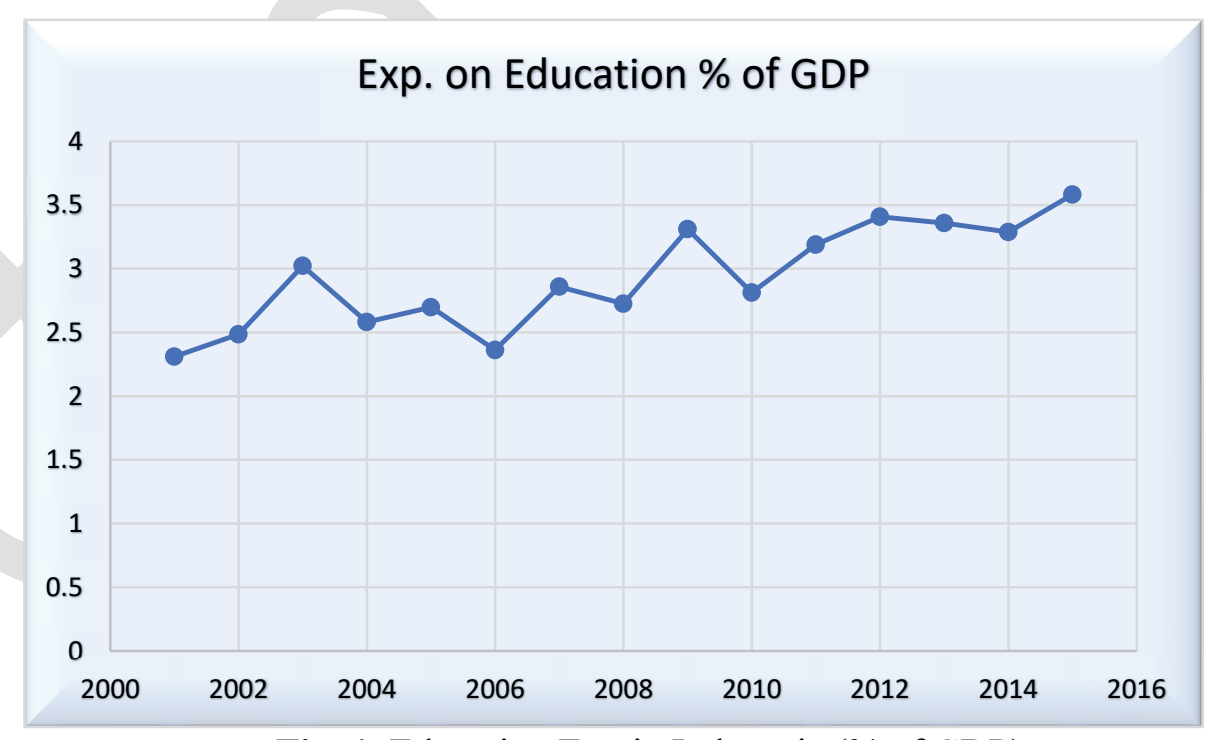

Fig. 1. Education Exp in Indonesia (\% of GDP)

Source : (WDI, 2018)

\section{Literature Review}

Public policy is covered in a range of research studies, both in developed and developing economies. Its significance has been reflected in the field of economy, social life and education management as well. For instance, Ahmed et al. (2013) explored the idea of public policy from the context of entrepreneurial orientation, self-employment, and leadership factors. The focus of research work is on 264 first generation expatriates from Lebanon through a mailing questionnaire approach. Findings of the study indicated that there was a significant association between the public policy indicators and education regarding the property rights and entrepreneurial orientation. However, the core limitation of the study explains the restricted indicators from the context of public policy. Meanwhile the significant implications cover the future research while taking the non-considered variables from both public policy and education sector. Another study conducted by Kuhlmann et al. (2008) provides an overview regarding the trends in public policy and professional development based on the diversity of the gender. Their work consists of social policy and governance indicators while focusing on health profession. Data was collected from various sources including case studies and secondary published materials. It was observed that for the betterment of professional development through gender diversity, social policies and 
governance indicators are adding their significant contributions. As per the implication, their study provides a new model for the management of public sector for the building of professional development.

Totterdill and Exton (2014) provided a theoretical contribution while discussing various ways through which policymakers were intervening for the innovation at workplace. For the ideological battleground, intervention from the government and regulation in overall economy are the key factors for the policy reforms in the region of United Kingdom. Atkinson (2014) examined the baseline of environmental policies with the application of sustainability concept. Based on the review of existing literature, they found that government was held responsible for the protection of environment because of industrial growth. Mismanagement is also observed regarding the policy processes and threatening the factor of sustainability. However, their study provides both the practical and social implications, where the social applications deals with the sustainability, as littles attention is devoted towards public policy and sustainability. During the time of late 90s, Dutta et al. (1999) analyzed the association between the public policy and education while dealing with the international comparison of expenditure on education and then its contribution in the economic growth and investment factors. Their findings indicate that risky nature of higher investment in education provides a new look for the development of better public policies. Some other studies also examined the association between the public polices and education (Anyon, 2014; Belfield \& Levin, 2015; Birkland, 2015; Bowe et al., 2017; Hornik, 2018; Jenson \& Fraser, 2015; Manzer, 1994; Sabatier, 2006; Vedung, 2017; Akuegwu \& Nwi-ue, 2017).

\section{Description of Variables}

Public policy is related to dealing with laws, regulations, governance mechanism and overall management guidelines which helps the government for the smooth working in a region or a country. The factors under the title of public policy indicate how various decisions are made in a region under specific priorities. These policies reflect the consideration of standards of livings, social and local cultures, and interaction between the government and public. These policies can be entitled as the work force development which covers the idea on how the individuals in the society will be cultivated for the social and economic growth (Giloth, 2000). The factor of public policy is also reflected through higher education in a specific region and related policies (Kogan \& Bauer, 2006). Such polices deal with the provision and growth of the advanced studies in the economy. While the concept of brain drain covers those policies which are directly or indirectly associated with the shifting of skilled individuals from the economy (Docquier et al., 2007). In addition, some other factors like public safety, constitutional convention and job approval are also entitled for the definition of public policies. Job approval provides a review on how various policies act regarding the provision of jobs for a specific workforce. Besides, the factor of legislature entitles the group of experts, responsible for the development of new laws and policies (Fiorino \& Ricciuti, 2007; Halder \& Chandra, 2012; Dumbu, 2014; Pan, 2014; Esia-Donkoh et al., 2015; Vahdany \& Gerivani, 2016; Ghanney, 2018; Kweka \& Ndibalema, 2018).

Education management deals with the principles, components, and various fields of studies, necessary for the perfect working or overall education system. For the consideration of education management, the present study explores the factors like achievements at elementary and higher school (Memon et al., 2010; Jayakumar, 2016; Verma et al., 2018; Owagbemi, 2018), number of enrollments in the college (Perna \& Titus, 2005), job market in the local region and job market in the international region as well. While the factors of overall education management is reflected through social improvements which describe the way through which community progress is evaluated (Chapman-Novakofski \& Karduck, 2005; Wijayanto \& Sumarwan, 2016; Vahdany \& Gerivani, 2016; Masciantonio \& Berger, 2018; AlFadley et al., 2018).

\section{Method of the Study}

To analyze the theoretical and empirical association between public policy indicators and education management, a survey questionnaire is proposed after an in depth study of the exiting literature. To consider the public policy, eight dimensions are added under the title of work force development, higher 
education, brain drain, public safety, constitutional convention, job approval, legislature and operation policies. While considering the factor of education management, six dimensions like achievements at elementary and high schools, college enrollments, job market in local \& international region and social improvements are observed. A scale of five points (don't know=1, not all successful=2, not particularly successful $=3$, somehow successful $=4$, and very successful $=5)$ is developed for the public policies. While for the education management, another five points (don't know $=1$, poor job done $=2$, an average job done $=3$, good job done $=4$, and excellent job done $=5$ ) is developed and added in the questionnaire. After the development process, questionnaire is presented to various individuals working in both public and private sectors with reasonable knowledge about public policies and education management in Indonesia. A final sample of 327 respondents is considered as pragmatic for the application of descriptive, regression and structural modelling techniques.

\section{Results and Discussion}

To understand the relationship between the factors of public policy and key indicators under the title of education management, descriptive findings are presented in Table 1. The mean score for work force development (WFD) is 4.085 according to Likert scale of five points, expressing that public policies regarding the work force are somehow successful. The value of standard deviation for this average trend is 1.275 , indicating a dispersion from the mean. For public policy in higher education (HE), average score of 4.20 explains that all the targeted respondents agreed that polices for higher education could develop some reasonable results. The value of standard deviation for higher education policies is 1.23, a reasonable deviation from the mean score. The factor of brain drains (BD) defines migration of highly qualified or trained individuals from the country. For BD, the average score of 3.12 explains that there was not very much transfer of such individuals from Indonesia to other regions of the world. The measurement scale for BD is ranging from high migration to very little migration, where the mean score of three reflects an average migration. As the factor of public safety (PS) is considered, the present study has also observed its importance. Respondents are requested to provide their valuable opinions about PS, and the mean score of 4.86 defines that overall consideration of PS in public policy is under good consideration and it is very successful. For constitutional convention, mean score of 2.88 indicates its little success in the region of Indonesia and respondents did not very much agree that $\mathrm{CC}$ factor had been highly successful. Descriptive findings for the factor of job approval (JA) maintains a mean score of 4.80, meaning that it was highly successful in the region. For legislature (LEG) known as the team responsible for the development of the public laws for the country, average score of 3.71 expresses the view point that respondents agreed with its successful laws creation. The factor of operational policies (OP) indicates a reasonable success in overall public policy indicator and explains that respondents were viewing it very successful in Indonesia.

\section{Table 1}

Descriptive Statistics

\begin{tabular}{lllrrr}
\hline Variable & Obs & Mean & Std.Dev. & Min & Max \\
\hline WFD & 327 & 4.085 & 1.275 & 1 & 1 \\
HE & 327 & 4.204 & 1.234 & 1 & 5 \\
BD & 327 & 3.142 & 1.336 & 1 & 5 \\
PS & 327 & 4.863 & 1.344 & 1 & 5 \\
CC & 327 & 2.881 & 1.377 & 1 & 5 \\
JA & 327 & 4.805 & 1.173 & 1 & 5 \\
LEG & 327 & 3.711 & 1.139 & 1 & 5 \\
OP & 327 & 4.551 & 1.227 & 1 & 5 \\
ESA & 327 & 3.772 & 1.115 & 1 & 5 \\
HEA & 327 & 3.602 & 1.143 & 1 & 5 \\
CE & 327 & 2.553 & 1.186 & 1 & 5 \\
JMLR & 327 & 3.641 & 1.047 & 1 & 5 \\
JMIR & 327 & 3.012 & .6325 & 1 & 5 \\
SI & 327 & 3.862 & 1.025 & & 5 \\
\hline
\end{tabular}


To study the factor of education management, first indicator is elementary school achievement (ESA) with an average score of 3.78, expressing an above average achievement on the scale. While for higher education achievement (HEA), mean value of 3.60 explains near to the average success. The factor of college enrollment (CE) indicates that it performed an average role in education management, while the average score of job market for international region (JMIR), average value from the respondents is 3.60, which explains the fact that job market is "very fair". For the factor of job market in international region (JMIR), mean response is 3.01 which explains a fair job opportunity for those who were graduated from the local universities. While the factor of social improvements explains that education is doing reasonable local and social growth in the economy.

Table 2 explains the level of association between the selected factors of public policy and education management. Correlation coefficient between WFD and HE is .28 indicating low level of position association between both factors. For the correlational between WFD and LEG, low association was observed. The association between PS and CC is .454 indicating a moderate level of relationship. Correlation coefficient between JA and LEG is .644 and between JA and OP is .632, indicating an above moderate level of correlation. For OP and JMIR a moderate level of association is examined with the coefficient value of .491. The rest of the indicators are explaining a reasonable level of association, hence expected that there was no issue for the high multiple independency between the selected factors of public policy and education in Indonesia.

Table 2

Matrix of correlations

\begin{tabular}{|c|c|c|c|c|c|c|c|c|c|c|c|c|}
\hline Variables & (1) & (2) & (3) & (4) & (5) & (6) & (7) & (8) & (9) & (10) & (11) & $(12)$ \\
\hline (1) WFD & 1.000 & & & & & & & & & & & \\
\hline (2) $\mathrm{HE}$ & 0.287 & 1.000 & & & & & & & & & & \\
\hline (3) $\mathrm{BD}$ & 0.208 & 0.312 & 1.000 & & & & & & & & & \\
\hline (4) PS & 0.277 & 0.254 & 0.250 & 1.000 & & & & & & & & \\
\hline (5) $\mathrm{CC}$ & 0.271 & 0.219 & 0.176 & 0.454 & 1.000 & & & & & & & \\
\hline (6) JA & 0.211 & 0.154 & 0.177 & 0.022 & 0.108 & 1.000 & & & & & & \\
\hline (7) LEG & 0.139 & 0.118 & 0.167 & 0.117 & 0.062 & 0.644 & 1.000 & & & & & \\
\hline (8) OP & 0.124 & 0.139 & 0.221 & 0.103 & 0.051 & 0.640 & 0.664 & 1.000 & & & & \\
\hline (9) ESA & 0.207 & 0.109 & 0.208 & 0.117 & 0.109 & 0.544 & 0.632 & 0.622 & 1.000 & & & \\
\hline (10) HEA & 0.111 & 0.112 & 0.138 & 0.143 & 0.053 & 0.440 & 0.525 & 0.537 & 0.572 & 1.000 & & \\
\hline (11) CE & 0.023 & 0.012 & 0.213 & 0.103 & 0.100 & 0.389 & 0.394 & 0.360 & 0.368 & 0.291 & 1.000 & \\
\hline (12) JMLR & 0.105 & 0.052 & 0.138 & 0.104 & 0.087 & 0.479 & 0.470 & 0.498 & 0.491 & 0.479 & 0.364 & 1.000 \\
\hline
\end{tabular}

To understand the significance of the overall correlation between the selected factors, the following hypothesis has been examined for the variance inflation factor (VIF) test as follows:

$\mathrm{H}_{0}$ : Correlation between the public policy indicators and education is problematic for the empirical findings.

$\mathrm{H}_{1}$ : Correlation between the public policy indicators and education is not problematic for the empirical findings.

\section{Table 3}

Variance inflation factor

\begin{tabular}{lrr}
\hline & VIF & $1 / \mathrm{VIF}$ \\
\hline OP & 2.123 & .471 \\
LEG & 2.119 & .472 \\
JA & 2.11 & .474 \\
PS & 1.404 & .712 \\
CC & 1.326 & .754 \\
WFD & 1.216 & .823 \\
HE & 1.213 & .825 \\
BD & 1.195 & .837 \\
MEAN VIF & 1.588 &. \\
\hline
\end{tabular}


To accept H1, VIF test has been applied and the related findings are presented in Table 3 . The value of VIF for OP, LEG and JA is above 2, while for the other indicators it is above 1 but below 2. The mean score for VIF is 1.588 , which indicates that there was no problem for the higher correlation between the selected variables, hence no problem for the multicollinearity. Therefore, H1 is accepted as the threshold point for the mean VIF is below 5 for the further consideration of factors in empirical results.

Table 4

Empirical Findings for first three indicators of education Management and Public Policy

\begin{tabular}{lccc}
\hline & $(1)$ & $(2)$ & $(3)$ \\
VARIABLES & ESA & HEA & $-0.0850^{* *}$ \\
\hline WFD & $0.0797^{* *}$ & 0.00196 & $(0.0531)$ \\
HE & $(0.0404)$ & $(0.0473)$ & $0.0979^{* *}$ \\
& $0.0358^{* * *}$ & 0.0110 & $(0.0509)$ \\
BD & $(0.0373)$ & $(0.0528)$ & $0.135^{* * *}$ \\
& -0.0430 & -0.00687 & $(0.0503)$ \\
PS & $(0.0331)$ & $(0.0434)$ & 0.0490 \\
& -0.00225 & $0.0770^{* * *}$ & $(0.0565)$ \\
CC & $(0.0392)$ & $(0.0477)$ & 0.0480 \\
& 0.0307 & -0.0246 & $(0.0499)$ \\
JA & $(0.0365)$ & $(0.0471)$ & $0.218^{* * *}$ \\
& 0.0899 & $0.0714^{* *}$ & $(0.0807)$ \\
LEG & $(0.0663)$ & $(0.0762)$ & $0.201^{* *}$ \\
OP & $0.336^{* * *}$ & $0.266^{* * *}$ & $(0.0823)$ \\
Constant & $(0.0726)$ & $(0.0827)$ & 0.0749 \\
Observations & $0.287^{* * *}$ & $0.286^{* * *}$ & $(0.0788)$ \\
R-squared & $(0.0597)$ & $(0.0707)$ & $1.586^{* * *}$ \\
\hline
\end{tabular}

Robust standard errors in parentheses

$* * * \mathrm{p}<0.01, * * \mathrm{p}<0.05, * \mathrm{p}<0.1$

After the descriptive and correlational analysis, Table 4 explains the impact of the selected factors for the public policy and their impacts on the first three indicators of education management under the title of elementary school achievements, high school achievements, and finally the college enrollment. Under the first regression model for ESA, the effect of WFD is found to be significant and positive, explaining that the work force development had a significant and positive influence on ESA with the coefficient of .0797 and standard error of .040 approximately. For HEA, the effect of WFD is found to be positive and insignificant, expressing that no change is observed for the public policy indicator through work force development on higher education achievements. For CE, the effect of WFD is .0850 , which explains that college enrollments were negatively associated with the work force developments. It is expressed that significant attention is required towards the relationship between the college enrollments and WFD and it is adversely affecting the education management in Indonesia. For the higher education, the effect on ESA is .0358 and significant at 1 percent level of significance. For HEA the effect of HE is found to be positively insignificant. While for CE the effect of HE is .0979 which explains that there was a significant and positive impact on college enrollment through higher education. This relationship implies that higher college enrollment creates a sense of responsibility in the society and more families will push their children to get the college enrollment. For the brain drain, the effect on ESA and HEA is negatively insignificant, which implies no impact on elementary school achievements, and higher school achievement through BD. However, for college enrollment, the effect of BD is found to be significant and positive with the coefficient of .135. It specifies that college enrollment is positively linked with BD. For public safety (PS), the effect on ESA and CE is found to be insignificant but for higher education achievement, its impact is positively significant at 1 percent. It implies that higher education achievements are increasing because of public safety in the region of Indonesia. To boost more such achievements, there is a significant need of public safety measures as reflected in public policies by Indonesian Government. For constitutional convention (CC), the effect on the first three indicators of education management implies that no effect was observed for the CC elementary school achievements, higher school achievements, college enrollment as well. 
For the factor of job approval as observed under public policies, it is examined that HEA and CE were significantly and positively associated with it. However, for legislature, the effect on ESA, HEA, and CE were $.336, .266$ and .201 respectively, which indicate a significant and positive influence on all three indicators of education management in Indonesia. The value of standard error for these coefficients are .0726, .0827 and .0749. Under the last indicator of public policy; operational policies, the effect on ESA is .287 and for HEA is .286 respectively. These coefficients are significantly describing that elementary school achievements and higher education achievements are significantly determined by OP for the whole sample of the study. However, for the CE, the effect of OP is found to be positively insignificant. The value of robust coefficient of determination for the first model is $.494, .348$ for the $2^{\text {nd }}$ model and .428 for the third regression model of the study. Table 5 presents the results of the regression findings for the last three indicators of education management under the title of job market in the local region, job market in the international region, and social improvements.

Table 5

Empirical Findings for last three indicators of education Management and Public Policy

\begin{tabular}{|c|c|c|c|}
\hline & -4 & -5 & -6 \\
\hline VARIABLES & JMLR & JMIR & SI \\
\hline \multirow[t]{2}{*}{ WFD } & -0.0024 & -0.0445 & 0.0217 \\
\hline & -0.0427 & -0.0498 & -0.0482 \\
\hline \multirow[t]{2}{*}{$\mathrm{HE}$} & -0.0507 & 0.0661 & -0.0373 \\
\hline & -0.0421 & -0.0527 & -0.0506 \\
\hline \multirow[t]{2}{*}{$\mathrm{BD}$} & $0.0149 * *$ & $0.00499 * * *$ & $0.029 * * *$ \\
\hline & -0.0371 & -0.0435 & -0.0431 \\
\hline \multirow[t]{2}{*}{ PS } & 0.0417 & 0.0679 & $0.0958 * *$ \\
\hline & -0.0489 & -0.054 & -0.0485 \\
\hline \multirow[t]{2}{*}{$\mathrm{CC}$} & 0.0202 & -0.0253 & -0.0311 \\
\hline & -0.0426 & -0.0514 & -0.0444 \\
\hline \multirow[t]{2}{*}{$\mathrm{JA}$} & $0.195 * *$ & -0.0283 & $0.142 *$ \\
\hline & -0.078 & -0.0731 & -0.0824 \\
\hline \multirow[t]{2}{*}{ LEG } & $0.147^{*}$ & $0.438 * * *$ & $0.300 * * *$ \\
\hline & -0.0802 & -0.0834 & -0.0864 \\
\hline \multirow[t]{2}{*}{ OP } & $0.213 * * *$ & $0.267 * * *$ & $0.198 * * *$ \\
\hline & -0.0653 & -0.0756 & -0.07 \\
\hline \multirow[t]{2}{*}{ Constant } & $1.542 * * *$ & $0.848 * * *$ & $1.046 * * *$ \\
\hline & -0.259 & -0.309 & -0.264 \\
\hline Observations & 327 & 327 & 327 \\
\hline R-squared & 0.391 & 0.372 & 0.357 \\
\hline
\end{tabular}

Robust standard errors in parentheses

$* * * \mathrm{p}<0.01, * * \mathrm{p}<0.05, * \mathrm{p}<0.1$

The effect of WFD for all the stated indicators under Table 5 is insignificant. Similar insignificant effect is observed from higher education. For the brain drain (BD), positive \& significant effect on JMLR is observed with the coefficient of .0149. For JMIR, the influence of .0049 is observed through BD. While for SI, this effect is .029 , significant at 1 percent. It implies that factor of brain drain is positively affecting the job market in local region, international region and social improvements in Indonesia. Through PS, only the factor of social improvement is found to be meaningful when the level of significance was 5 percent. The factor of constitutional convention is also indicating an insignificant impact on all three indicators of education management as presented in Table 5. For JA, it is examined that JMLR is positively and significantly associated with it but insignificantly linked with JMIR. As a common phenomenon, job approval can lead towards the social improvement and similar relationship is observed. The effect of JA on SI is .142 which explains that there was a significant and positive relationship between both factors. The factor of legislature explains that there were significant and positive influence of .147, .438 and .300 on education indicators (JMLR, JMIR, SI). For the operational policies, the effect on all the factors is found to be significant at 1 percent, indicating a higher impact on the last three indicators of education management. Besides, the explanatory power of robust coefficient of determination for the last three indicators of education management are $.391, .372$, and .357 respectively. 
After the regression analysis, structural equation model (SEM) has been developed and presented in Fig. 1. The reason for developing a SEM is based on its significance in existing literature, vigorous empirical findings and covering the standardized regression estimates, based on the provided sample. However, before conducting SEM technique for the discussion of in depth association between the public policy and education management, factor analyses have been conducted, providing a factor loading for each of the item under public policy and education management. Table 6 presents the factor loading for all the items. It is found that all the factors were above .50 factor loading

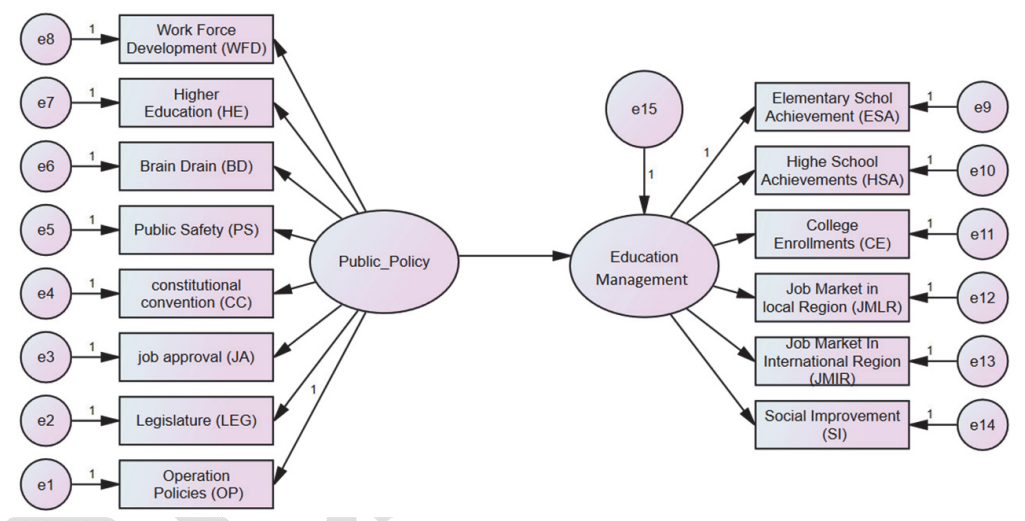

Fig. 1. Structural Model for Public Policy and Education Management

Table 6

Factor Loadings and Reliability Findings

\begin{tabular}{|c|c|c|c|}
\hline Variable Title & Factor Title & $\begin{array}{c}\text { Factor } \\
\text { Loadings }\end{array}$ & Chron-Bach Alpha \\
\hline \multirow{8}{*}{ Public Policy } & Work Force Development (WFD) & .81 & \multirow{9}{*}{.72} \\
\hline & Higher Education (HE) & .73 & \\
\hline & Brain Drain (BD) & .69 & \\
\hline & Public Safety (PS) & .72 & \\
\hline & Constitutional Convention (CC) & .74 & \\
\hline & Job Approval (JA) & .76 & \\
\hline & Legislature (LEG) & .83 & \\
\hline & Operational Policies (OP) & .82 & \\
\hline & Elementary School Achievement (ESA) & .77 & \\
\hline \multirow{5}{*}{$\begin{array}{c}\text { Education Man- } \\
\text { agement }\end{array}$} & Higher Educational Achievement (HEA) & .71 & \multirow{5}{*}{.82} \\
\hline & College Enrollment (CE) & .66 & \\
\hline & Job Market in Local Region (JMILR) & .65 & \\
\hline & Job Market in International Region (JMIR) & .73 & \\
\hline & Social Improvements (SI) & .73 & \\
\hline
\end{tabular}

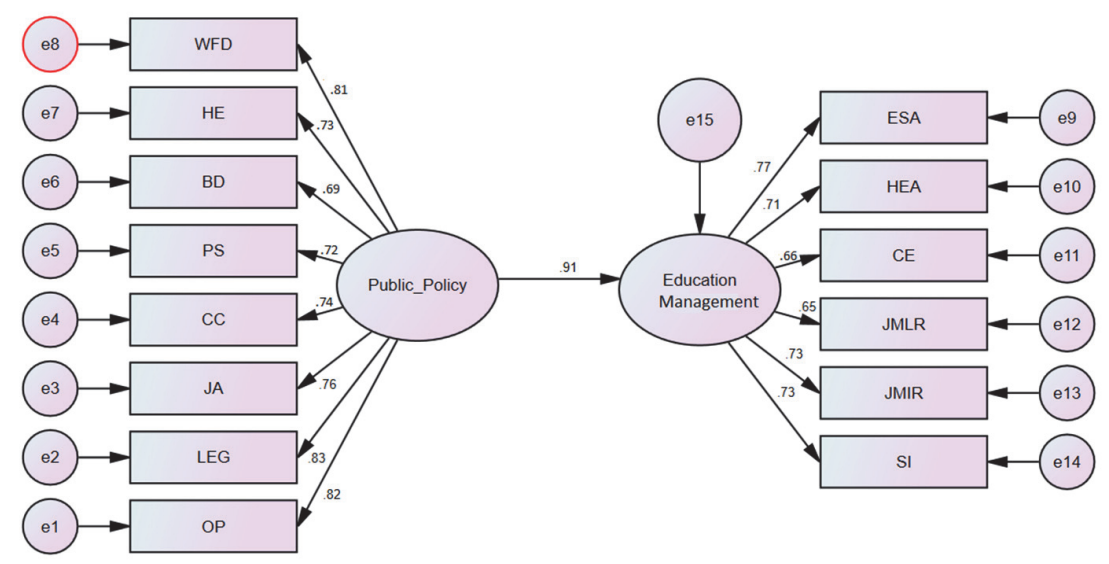

Fig. 2. Model Output for Public Policy and Education Management 
Table 7 explains the findings for the SEM approach applied through SPSS-AMOS22. The value of regression estimate for the public policy on education is .782 which indicates an overall impact of public policy on Education Management in Indonesia. For the structural modelling, a regression weight of 1 is assigned to OP. To predict the value of LEG, it is found that public policy had a coefficient of .942 and significant at 1 percent level of significance. For JA, the value of coefficient is .888 and for $\mathrm{CC}$ it is .167. All the stated indicators of public policy have explained their significant association with overall level of public policy. The coefficient of each factor of education management are also indicating their significant associations with it as presented under Table 7 of the study. While for ESA, a standard regression weight of 1 is assigned under structural modelling application procedure.

\section{Table 7}

Regression values for Public Policy and Education Management

\begin{tabular}{|c|c|c|c|c|c|c|}
\hline Items & Directions & Variables & Estimate & S.E. & C.R. & $\mathrm{P}$ \\
\hline Education_Mgt & $\leftarrow$ & Public_Policy & .782 & .057 & 13.688 & $* * *$ \\
\hline OP & $\leftarrow$ & Public_Policy & 1.000 & & & \\
\hline LEG & $\leftarrow$ & Public_Policy & .942 & .057 & 16.567 & $* * *$ \\
\hline JA & $\leftarrow$ & Public_Policy & .888 & .060 & 14.833 & $* * *$ \\
\hline $\mathrm{CC}$ & $\leftarrow$ & Public_Policy & .167 & .080 & 2.083 & $.037 * *$ \\
\hline PS & $\leftarrow$ & Public_Policy & .219 & .078 & 2.805 & $.005^{* *}$ \\
\hline $\mathrm{BD}$ & $\leftarrow$ & Public_Policy & .346 & .077 & 4.507 & $* * *$ \\
\hline $\mathrm{HE}$ & $\leftarrow$ & Public_Policy & .229 & .071 & 3.199 & $.001 * *$ \\
\hline WFD & $\leftarrow$ & Public_Policy & .267 & .074 & 3.616 & $* * *$ \\
\hline ESA & $\leftarrow$ & Education_Mgt & 1.000 & & & \\
\hline HEA & $\leftarrow$ & Education_Mgt & .941 & .072 & 13.016 & $* * *$ \\
\hline $\mathrm{CE}$ & $\leftarrow$ & Education_Mgt & .706 & .077 & 9.111 & $* * *$ \\
\hline JMLR & $\leftarrow$ & Education_Mgt & .790 & .067 & 11.808 & $* * *$ \\
\hline JMIR & $\leftarrow$ & Education_Mgt & 1.047 & .078 & 13.379 & $* * *$ \\
\hline SI & $\leftarrow$ & Education_Mgt & .970 & .073 & 13.325 & $* * *$ \\
\hline
\end{tabular}

Table 8 explains the standardized value of regression coefficients, which implies the adjustment of standard error in unstandardized coefficients. All these stated coefficients are found to be significant at 1 percent and 5 percent level of significance in Table 8. Fig. 2 explains the overall factor loadings for each of the item with overall standard regression impact of public policy on education management for the whole sample of the study.

Table 8

Standardized Regression values for Public Policy and Education Management

\begin{tabular}{lccc}
\hline Variables \& Items & Directions & Variables \& Items & Estimate \\
\hline Education_Mgt & $\leftarrow$ & Public_Policy & $.908^{* * *}$ \\
OP & $\leftarrow$ & Public_Policy & $.817^{* * *}$ \\
LEG & $\leftarrow$ & Public_Policy & $.829^{* * *}$ \\
JA & $\leftarrow$ & Public_Policy & $.759^{* *}$ \\
CC & $\leftarrow$ & Public_Policy & $.122^{* *}$ \\
PS & $\leftarrow$ & Public_Policy & $.163^{* *}$ \\
BD & $\leftarrow$ & Public_Policy & $.260^{* * *}$ \\
HE & $\leftarrow$ & Public_Policy & $.186^{* *}$ \\
WFD & $\leftarrow$ & Public_Policy & $.210^{* * *}$ \\
ESA & $\leftarrow$ & Education_Mgt & $.774^{* * *}$ \\
HEA & $\leftarrow$ & Education_Mgt & $.710^{* * *}$ \\
CE & $\leftarrow$ & Education_Mgt & $.514^{* * *}$ \\
JMLR & $\leftarrow$ & Education_Mgt & $.652^{* * *}$ \\
JMIR & $\leftarrow$ & Education_Mgt & $.728^{* * *}$ \\
SI & $\leftarrow$ & Education_Mgt & $.725^{* * *}$ \\
\hline
\end{tabular}

\section{Conclusions}

For the significant economic and social development, public policy in various types plays a vital role. Meanwhile for the education sector, its importance is not the one which can be denied. The purpose of 
present study was to examine the key factors under the title of public policy and its association with education management from the context of Indonesia. For public policy eight indicators have been finalized, while for education, six dimensions were added in the model. Both descriptive and empirical findings were also presented. It was observed that education management factors like WFD were significantly affecting the elementary school achievement. For HE, the effect was found to be significantly positive on ESA and CE, while BD was significantly impacting on the value of CE for the whole sample of the study. Meanwhile the factors of PS \& JA were significantly associated with HEA. One of the meaningful contributions of the study was the impact of LEG on the first three indicators of public policy. While for operational policies, the effect was significant and positive for elementary school and higher education achievements. Under the findings of regression models, authors have observed that brain drain was positively linked to job market both at national \& international level, and social improvements. After the regression model, structural equation model was applied indicating a good factor loading for all items along with reliability analysis. Findings of the structural equation modelling have indicated that the overall significant and positive influence was found for the public policy on education management.

For the further consideration of the study, it is suggested that the idea of public policy be expanded to the field of education like entrepreneurship and other fields of business and economy. The significant contribution of the present is to cover the gap in the present literature from the context of public policy and education management in Indonesia. Findings under the present study have indicated that strong and significant attention were required towards those factors which are entitled under public policy and have maintained negative influence on education. Besides, the core limitations of the study are considered as the limited indicators for the public policy and education management. Future research can be conducted while adding the factors like financial policies in the form of fiscal and monetary with the impact on education management along with some fringe benefits.

\section{References}

Ahmed, Z. U., Zgheib, P. W., Carraher, S., \& Kowatly, A. K. (2013). Public policy and expatriate entrepreneurs. Journal of Entrepreneurship and Public Policy, 2(1), $42-53$.

Akuegwu, B. A., \& Nwi-ue, F. D. (2017). Providing Academic Leadership in Universities in Cross River State, Nigeria: Assessment of Departmental Heads' Effectiveness. Asian Journal of Education and Training, 3(1), 18-24.

Al-Fadley, A., Al-Holy, A., \& Al-Adwani, A. (2018). Teacher Perception of Parents Involvement in their Children's Literacy and their Reading Instructions in Kuwait EFL Primary School Classrooms. International Journal of Education and Practice, 6(3), 120-133.

Anyon, J. (2014). Radical possibilities: Public policy, urban education, and a new social movement. Routledge.

Atkinson, L. C. (2014). Public policy processes and the environment: implications for a sustainable future. Sustainability Accounting, Management and Policy Journal, 5(4), 457-475.

Belfield, C. R., \& Levin, H. M. (2015). Privatizing educational choice: Consequences for parents, schools, and public policy. Routledge.

Birkland, T. A. (2015). An introduction to the policy process: Theories, concepts, and models of public policy making. Routledge.

Bowe, R., Ball, S. J., \& Gold, A. (2017). Reforming education and changing schools: Case studies in policy sociology. Routledge.

Chapman-Novakofski, K., \& Karduck, J. (2005). Improvement in knowledge, social cognitive theory variables, and movement through stages of change after a community-based diabetes education program. Journal of the American Dietetic Association, 105(10), 1613-1616.

Docquier, F., Lohest, O., \& Marfouk, A. (2007). Brain drain in developing countries. The World Bank Economic Review, 21(2), 193-218. 
Dumbu, E. (2014). Promoting entrepreneurship through open and distance education in Zimbabwe. A case study of the Zimbabwe Open University students at Masvingo Regional Campus. International Journal of Business, Economics and Management, 1(6), 101-114.

Dutta, J., Sefton, J., \& Weale, M. (1999). Education and public policy. Fiscal Studies, 20(4), 351-386.

Esia-Donkoh, K., Amihere, A. K., \& Addison, A. K. (2015). Assessment of student internship programme by 2013/2014 final year students of the department of basic education, University of Education, Winneba, Ghana. Humanities and Social Sciences Letters, 3(2), 105-120.

Fiorino, N., \& Ricciuti, R. (2007). Legislature size and government spending in Italian regions: Forecasting the effects of a reform. Public Choice, 131(1-2), 117-125.

Ghanney, R. A. (2018). How parental education and literacy skill levels affect the education of their wards: The case of two schools in the Effutu municipality of Ghana. International Journal of Education and Practice, 6(3), 107-119.

Giloth, R. P. (2000). Learning from the field: Economic growth and workforce development in the 1990s. Economic Development Quarterly, 14(4), 340-359.

Halder, S. N., \& Chandra, S. (2012). Users'Attitudes towards Institutional Repository in Jadavpur University: A Critical Study. International Journal of management and Sustainability, 1(2), 45-52.

Hornik, R. (2018). Public health education and communication as policy instruments for bringing about changes in behavior Social marketing (pp. 45-58). Psychology Press.

Jayakumar, R. (2016). Opinion of the university teachers towards educational television programmes. American Journal of Education and Learning, 1(1), 45-52.

Jenson, J. M., \& Fraser, M. W. (2015). Social policy for children and families: A risk and resilience perspective. Sage Publications.

Kogan, M., \& Bauer, M. (2006). Higher education policies: Historical overview Transforming Higher Education (pp. 25-38). Springer.

Kuhlmann, E., \& Lynn Bourgeault, I. (2008). Gender, professions and public policy: new directions. Equal Opportunities International, 27(1), 5-18.

Kweka, K. H., \& Ndibalema, P. (2018). Constraints hindering adoption of ICT in government secondary schools in Tanzania: The case of Hanang district. International Journal of Educational Technology and Learning, 4(2), 46-57.

Manzer, R. A. (1994). Public Schools and Political Ideas: Canadian Educational Policy in Historical Perspective. ERIC.

Masciantonio, T. A., \& Berger, P. D. (2018). Is alumni salary an appropriate metric for university marketers?. Journal of Social Economics Research, 5(1), 1-9.

Memon, G., Joubish, F., \& Khurram, A. (2010). Impact of parental socio-economic status on students' educational achievements at secondary schools of district Malir, Karachi. Middle-East Journal of Scientific Research, 6(6), 678-687.

Owagbemi, G. O. (2018). Assessing the relocation of Adekunle Ajasin University to Akokoland on transportation system and rural development in Ondo State. Humanities and Social Sciences Letters, 6(2), 51-58.

Pan, C. Y. (2014). Effects of reciprocal peer-questioning instruction on EFL college students english reading comprehension. International Journal of English Language and Literature Studies, 3(3), 190-209.

Perna, L. W., \& Titus, M. A. (2005). The relationship between parental involvement as social capital and college enrollment: An examination of racial/ethnic group differences. The Journal of Higher Education, 76(5), 485-518.

Sabatier, P. A. (2006). Policy change and learning: An advocacy coalition approach (theoretical lenses on public policy).

Totterdill, P., \& Exton, R. (2014). Public policy for productive and healthy workplaces. Strategic Direction, 30(9), 38-40.

Vahdany, F., \& Gerivani, L. (2016). An analysis of the English language needs of medical students and general practitioners: A case study of Guilan University of Medical Sciences. International Journal of English Language and Literature Studies, 5(2), 104-110. 
Vedung, E. (2017). Public policy and program evaluation. Routledge.

Verma, C., Stoffova, V., \& Zoltán, I. (2018). Perception difference of Indian students towards information and communication technology in context of university affiliation. Asian Journal of Contemporary Education, 2(1), 36-42.

WDI. (2018). Government expenditure on education, total (\% of GDP). Retrieved December 10, 2018, from https://data.worldbank.org/indicator/SE.XPD.TOTL.GD.ZS

Wijayanto, H., \& Sumarwan, U. (2016). Analysis of the factors influencing Bogor senior high school student choice in choosing Bogor Agricultural University (Indonesia) for further study. Journal of Education and e-Learning Research, 3(3), 87-97.

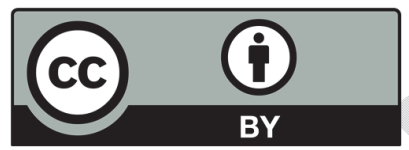

(C) 2019 by the authors; licensee Growing Science, Canada. This is an open access article distributed under the terms and conditions of the Creative Commons Attribution (CC-BY) license (http://creativecommons.org/licenses/by/4.0/). 